\title{
PHYTOTOXIC ACTIVITY OF DIFFERENT PLANT PARTS OF Drimys brasiliensis MIERS ON GERMINATION AND SEEDLING DEVELOPMENT
}

\author{
ATIVIDADE FITOTÓXICA DE DIFERENTES PARTES DE Drimys brasiliensis \\ MIERS NA GERMINAÇÃO E DESENVOLVIMENTO DE PLÂNTULAS
}

\section{Simoni ANESE ${ }^{\mathbf{1}}$; Patrícia Umeda GRISI ${ }^{1}$; Luciana de Jesus JATOBÁ ${ }^{1}$; Viviane de Cassia PEREIRA ${ }^{1}$; Sonia Cristina Juliano GUALTIERI ${ }^{2}$.}

1. Doutorandas, Programa de Pós-graduação em Ecologia e Recursos Naturais, Universidade Federal de São Carlos, São Carlos, SP, Brasil. simonianese@ yahoo.com.br; 2. Professora titular, Departamento de Botânica, Universidade Federal de São Carlos, São Carlos,

SP, Brasil.

\begin{abstract}
The aim of this study was to evaluate the phytotoxic activity of aqueous extracts from mature leaves, stem bark and roots of Drimys brasiliensis Miers on germination and initial seedling development of two target species, Triticum aestivum L. (wheat) and Raphanus sativus L. (radish). The aqueous extract was prepared in a proportion of $10 \mathrm{~g}$ of plant powder, dissolved in $100 \mathrm{~mL}$ of distilled water, resulting in a $10 \%$ extract concentrate. Dilutions were made with distilled water to $7.5 ; 5.0 ; 2.5 \%$ and $0 \%$ (control). Germination and seedling growth bioassays were carried out under controlled laboratory conditions. The different plant parts exerted inhibitory effects on germination and early growth of wheat and radish, however, the extract obtained from the leaves was more effective in inhibiting the germination of radish. All plant parts of $D$. brasiliensis may constitute a promising source in the search for compounds capable of acting as natural phytotoxins.
\end{abstract}

KEYWORDS: Inhibition. Casca d'anta. Wheat. Radish. Germination. Early growth.

\section{INTRODUCTION}

During evolutionary history, plants have developed biosynthetic routes to synthesize and accumulate a wide variety of secondary metabolites; these routes respond to the characteristics of the environment where they occur (CALLAWAY, 2002). Many of these natural products play an important role in the interaction between plants with their environment and in particular, with their biotic environment, where they may serve as attractants for pollinators or seed dispersers, as a defense against natural enemies, or as allelochemicals against other plant competitors (KROYMANN, 2011).

The discovery of special metabolites involved in allelopathic interactions may be an important source of new chemical structures that are useful for the production of molecules that can be used in the agrochemical industry (MACÍAS et al., 2008). Many plant extracts or allelochemicals exhibit a wide spectrum of activity against pests and have long been touted as attractive alternatives to synthetic chemical pesticides for pest management because they pose little threat to the environment or to human health (KOUL; WALIA et al., 2009). Additionally, allelochemicals degrade more rapidly and contain fewer halogen substituents than synthetic herbicides (FAROOQ et al., 2011).
Allelochemicals are found in all plant organs including roots, rhizomes, leaves, bark and seeds. However, within a single species, the amount may vary among different plant parts, as noted by Gatti et al. (2010) in Aristolochia esperanzae O. Kuntze, by Souza-Filho et al. (2010) in three Copaiferae species, and by $\mathrm{Wu}$ et al. (2009) in Mikania micrantha. These compounds can be considered phytotoxic depending on their allelopathic action, bioactive concentration, persistence and form in which they are released in the environment (INDERJIT; DUKE, 2003). When seeds of susceptible species are exposed to allelochemicals, germination can be inhibited; if this occurs, the seedlings may exhibit reductions in growth and development or abnormal metabolism. The most commonly observed effects are a delay in germination time, atrophy and thickened root, root growth reduction, primary or secondary root absence and hypocotyl growth reduction (GATTI et al., 2010; GUSMAN et al., 2011; GRISI et al., 2012; SILVESTRE et al., 2013).

The genus Drimys (Winteraceae), commonly known in Brazil as "cataia" and "casca d'anta", comprises seven species distributed from the Strait of Magellan in South America to southern Mexico. Three species grow wild in Brazil, Drimys angustifolia Miers, D. brasiliensis Miers and $D$. roraimensis (A. C. Sm.) Ehrend. and Gottsb. The first two species occur in Southern Brazil, and the 
last occurs in the Amazonian forest (EHRENDORFER et al., 1979; MELLO-SILVA, 2013). In folk medicine, the genus Drimys is used as a stimulant and as a tonic, as analgesic and antiinflammatory agents, and to treat ulcers, diarrhea, cancer and infections of the respiratory tract (TRINTA; SANTOS, 1997).

The species Drimys brasiliensis Miers is found in the Atlantic Forest and in gallery forests that extend into the Cerrado domain (EHRENDORFER et al., 1979; LORENZI, 2002) and its chemical composition and biological activity have been extensively investigated. In this species, sesquiterpene drimanes are predominant, including polygodial, 1- $\beta$-(p-methoxycinnamoyl)-polygodial and drimanial (MENDES et al., 1998; CECHINELFILHO et al., 1998; MALHEIROS et al., 2001; 2005). These compounds exhibit antinociceptive (EL-SAYAH et al., 2000), antihyperalgesic (MENDES et al., 1998), antifungal (MALHEIROS et al., 2005), anti-inflammatory (LAGO et al., 2010), antibacterial (SILVEIRA et al., 2012), leishmanicidal and antimalarial activities (CORRÊA et al., 2011; CLAUDINO et al., 2013). However, few studies have examined the phytotoxicity of $D$. brasiliensis on other plants.

In this context, the aim of this study was to evaluate the phytotoxic effects of different $D$. brasiliensis plant parts on the germination and early growth of some crop plants.

\section{MATERIAL AND METHODS}

\section{Collection of plant material and preparation of extracts}

Different plant parts of $D$. brasiliensis subsp. brasiliensis were collected from plants occurring in the reserve area of cerrado "sensu strictu" on the campus of São Carlos Federal University (UFSCar) in São Carlos-SP $\left(22^{\circ} 02^{\prime} \mathrm{S}\right.$ and $47^{\circ} 52^{\prime} \mathrm{W}$ ), Brazil. A voucher specimen was deposited at the Herbarium of the Department of Botany of São Carlos Federal University under registration number HUFSCar 8339. Mature leaves, roots and stem bark were collected in August 2010.

After collection, the plant parts were dried in an oven equipped with forced air circulation at 40 ${ }^{\circ} \mathrm{C}$ for $72 \mathrm{~h}$. Later, the plant parts were pulverized in an electric mill, weighed, vacuum packaged in plastic bags and stored at $\pm 4{ }^{\circ} \mathrm{C}$. From the dry plant material (powder) prepared from the various plant parts, treatment extracts were produced by stirring the powder into distilled water (10\% weight/volume, $\mathrm{g} \mathrm{mL}^{-1}$ ). The extracts were left to stand in the dark for $24 \mathrm{~h}$ at $4{ }^{\circ} \mathrm{C}$ before vacuum filtration using an electric pump coupled to a Buchner funnel that was lined internally with filter paper (GATTI et al., 2004). The resulting 10\% extracts were diluted to concentrations of 10.0, 7.5, 5.0, 2.5 and $0 \%$ (control).

Phytotoxic effects were evaluated based on bioassay diaspore germination and early growth of seedlings. Wheat (Triticum aestivum L., BRS 264, Poaceae) and radish (Raphanus sativus L., variety Vip Crimson, Brassicaceae) were used as the target species.

\section{Osmotic potential and $\mathrm{pH}$ of the extracts}

The $\mathrm{pH}$ of the extracts was measured using an Analion pH meter, model PM608, and the molar concentration was measured using an automatic osmometer ( $\mu$ Osmotte, model 5004). The osmotic potentials of the most concentrated leaf, bark and root extracts $(10 \%)$ were calculated.

\section{Germination bioassay}

Bioassay was conducted in $90-\mathrm{mm}$ (diameter) Petri dishes containing two sheets of filter paper moistened with $5 \mathrm{~mL}$ of distilled water (control) or various concentrations of the extracts obtained from the powders of $D$. brasiliensis bark, roots and leaves. Each plate received 25 diaspores of the target species; four replicates were used for each extract, and the dishes were capped and sealed with plastic film. The experiment was conducted in a germination chamber at $25^{\circ} \mathrm{C}$ under a photoperiod of $12 \mathrm{~h} \mathrm{light} / 12 \mathrm{~h}$ dark. The experimental design was completely randomized. The germination criterion was embryo protrusion and was evaluated every $12 \mathrm{~h}$ during the first seven days and at intervals of $24 \mathrm{~h}$ until germination was zero for three consecutive days. The germinability, mean germination time (MGT) and Maguire's Germination Speed Index (GSI) were calculated according to Ranal and Santana (2006).

To assess the osmotic effect of the extracts, germination bioassays with wheat and radish diaspores were performed using solutions of polyethylene glycol 6000 (PEG 6000) to -0.26 , 0.14 and $-0.08 \mathrm{MPa}$, the same osmotic concentrations used to prepare $10 \%$ extracts of the leaf, stem and root of $D$. brasiliensis, respectively, according to Michel and Kaufmann (1973); the control was $0 \mathrm{MPa}$. The experiment was performed adopting the same methodology as that described for the germination bioassay.

\section{Seedling growth bioassay}

To standardize the size of the plants in the growth bioassay, approximately 50 target plant 
diaspores were germinated in 15-mm Petri dishes containing filter paper moistened with distilled water. The plates were capped, wrapped with plastic film and placed in a germination chamber under the same conditions as those adopted for the germination bioassay. Seedlings with 3-mm (length) roots were selected and transferred to transparent plastic boxes $(15 \times 10 \times 5 \mathrm{~cm})$. The boxes were lined with two sheets of filter paper moistened with $8 \mathrm{~mL}$ of various concentrations of the extracts obtained from the D. brasiliensis plant parts and distilled water (control); 10 seedlings were transferred into each box, and four replications were performed for each treatment. The boxes were capped and maintained under the same conditions as those mentioned for the germination bioassay. After seven days, the shoot and primary root lengths of the seedlings were measured using a digital caliper.

\section{Statistical Analysis}

The data were subjected to normality (Shapiro-Wilk) and homogeneity (Levene) tests. When these two assumptions were met, an analysis of variance (ANOVA) was applied. The linear or quadratic regression models used were adjusted
ANESE, S. et al.

when the ANOVA $F$ was significant. The goodness of the models was tested at 0.05 significance and was evaluated based on the coefficient of determination $\left(\mathrm{R}^{2}\right)$. For the variables that showed no significant differences between treatments, means are presented in the figures together with their standard deviations. To compare the effects caused by the various plant parts of $D$. brasiliensis, conjoint analysis was performed for the characteristics in which the ratio between the larger and smaller residual mean square was not greater than 7 (PIMENTEL-GOMES, 1990).

\section{RESULTS AND DISCUSSION}

The different plant parts of $D$. brasiliensis inhibited wheat and radish. When treated with aqueous leaf extracts, the germination and early growth of both species were inhibited. The germination of the wheat caryopses was linearly reduced by $1.16 \%$ for each $0.01 \mathrm{~g} \mathrm{~mL}^{-1}$ of leaf extract added, and radish germination was completely inhibited by the $10 \%$ solution (Figure 1A).
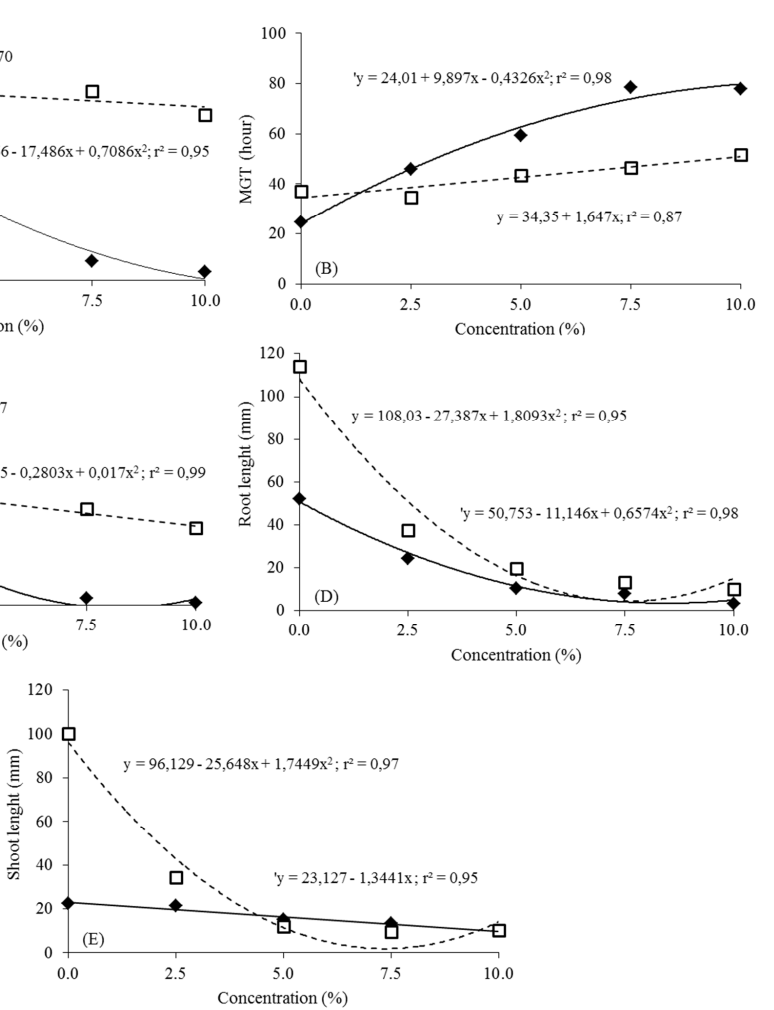

$\rightarrow$ radish ('y)

$\square$ wheat (y)

Figure 1. (A) Germination (G\%), (B) mean germination time (MGT), (C) Maguire's Index in wheat ( $T$. aestivum) and radish (R. sativus), early growth of (D) roots and (E) shoots when treated with $D$. brasiliensis Miers leaf extract at various concentrations. 
The mean germination time of radish seeds was maximal ( $80.88 \mathrm{~h}$ ) using the $10 \%$ solution, and the germination speed was zero at the estimated concentration of $8.23 \%$. For wheat caryopses, the mean germination time $(1.647 \mathrm{~h})$ increased linearly; consequently, a linear reduction in the germination speed $\left(0.029\right.$ seed $\left.\mathrm{h}^{-1}\right)$ was observed for each addition of $0.01 \mathrm{~g} \mathrm{~mL}^{-1}$ of leaf extract (Figure 1B and $1 \mathrm{C}$ ). The minimum values of early root growth in wheat $(42 \mathrm{~mm})$ and radish $(28 \mathrm{~mm})$ were observed when using estimated concentrations of 7.60 and $8.5 \%$, respectively (Figure 1D). The early shoot growth of radish decreased linearly by 1.34 $\mathrm{mm}$ for each $0.01 \mathrm{~g} \mathrm{~mL}^{-1}$ of leaf extract added. For wheat, the shortest length $(9 \mathrm{~mm})$ was observed when using an estimated concentration of $7.36 \%$ (Figure 1E).

Similar results were obtained for the germination and early growth inhibition of radish using aqueous leaf extracts of Andira humilis (PERIOTTO et al., 2004), Cyperus rotundus (ANDRADE et al., 2009) and Solanum americanum (BORELLA et al., 2012). Wheat caryopses treated
ANESE, S. et al.

with aqueous leaf extracts of Fumaria indica and Polygonum plebejum also exhibited inhibited germination and seedling growth (ULLAH et al., 2013). In contrast, treatment with leaf extracts of Jatropha curcas (REICHEL et al., 2013) and Euphorbia dracunculoides (TANVEER et al., 2012) affected the growth of wheat but did not affect germination. All plants produced secondary metabolites, but these differed in quality and quantity among species. Tolerance or resistance to these compounds can also be specific, as species are more sensitive than others (FERREIRA; ÁQUILA, 2000).

The aqueous stem bark extracts of $D$. brasiliensis also significantly inhibited the evaluated parameters in wheat and radish. There was a linear reduction in germination $(1.08 \%$ and $2.28 \%$ for each addition of $0.01 \mathrm{~g} \mathrm{~mL}^{-1}$ of extract in wheat and radish, respectively) and a linear increase in the mean germination time (1.91 and 2.37 hours for each addition of $0.01 \mathrm{~g} \mathrm{~mL}^{-1}$ of extract in wheat and radish, respectively) (Figure 2A and 2B).
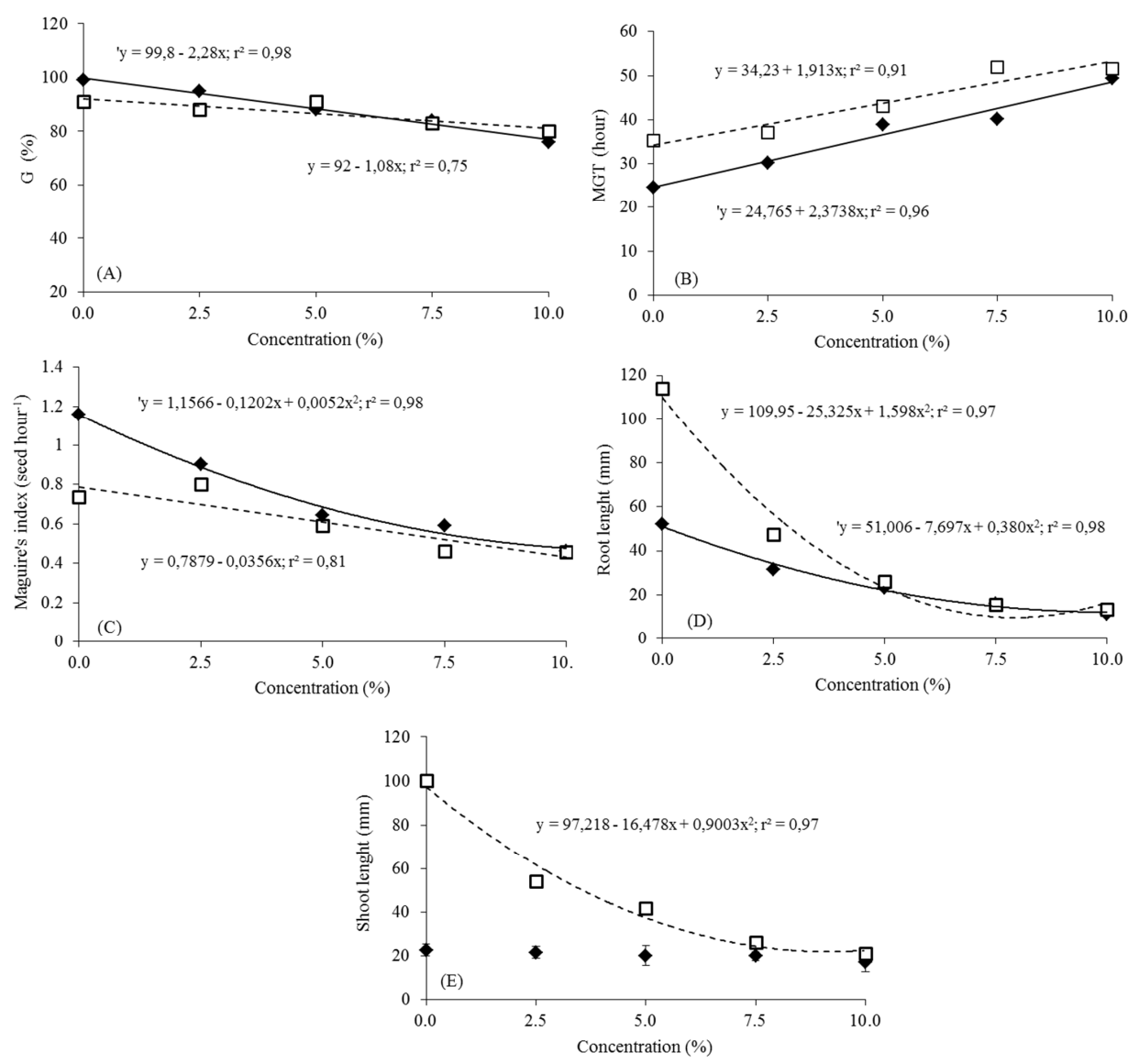

radish ('y)

$\square$ wheat (y)

Figure 2. (A) Germination (G\%), (B) mean germination time (MGT), (C) Maguire's Index in wheat (T. aestivum) and radish ( $R$. sativus), early growth of (D) roots and (E) shoots early growth when treated with $D$. brasiliensis Miers stem bark extract at various concentrations. 
The germination speed index of wheat caryopses decreased linearly by 0.021 seed hour $^{-1}$ for each $0.01 \mathrm{~g} \mathrm{~mL}^{-1}$ of extract added. In radish seeds, the minimum value of 0.43 seed hour ${ }^{-1}$ was achieved when treating with $10 \%$ extract (Figure $3 \mathrm{C})$. The minimum values of early root growth in wheat $(9.61 \mathrm{~mm})$ and radish $(12.03 \mathrm{~mm})$ were observed when using estimated concentrations of 7.9 and $12.03 \%$, respectively (Figure 2D). Treatment with stem bark extract did not significantly affect the growth of radish shoots but did affect wheat: shorter roots $(21.88 \mathrm{~mm})$ were observed when treating with an estimated concentration of $9.15 \%$ (Figure 2E).

The stem bark of $D$. brasiliensis is of great ethnobotanical value in Brazil because it is used as a medicinal plant with antifungal, antibacterial, antiinflammatory and antiallergic properties to treat pain and malaria, and many scientific studies have demonstrated these properties (CECHINEL-FILHO et al., 1998; MALHEIROS et al., 2001; 2005; SILVEIRA et al., 2012; CLAUDINO et al., 2013). Moreover, several sesquiterpene compounds that are
ANESE, S. et al.

related to these medicinal properties have been isolated from the stem bark of this species (MALHEIROS et al., 2001); these compounds might also play a role in the phytotoxic effects observed for this species, since in this study we observed the phytotoxic effects on the germination and early growth of wheat and radish. Extracts derived from the stem bark of plants constitute an important source of allelopathic substances that inhibit the early growth of lettuce seedlings (VIRTUOSO; MIGUEL, 2005) and also been used for weed control (SOUZA-FILHO; ALVES, 2000).

The aqueous root extracts of $D$. brasiliensis also showed phytotoxic effects on wheat and radish as reflected in most of the variables studied. There was a linear decrease in radish germination $(2.6 \%$ for each $0.01 \mathrm{~g} \mathrm{~mL}^{-1}$ of extract added), but no significant effect on wheat caryopses was recorded (Figure 3A). A linear increase in mean germination time was recorded for both species (1.11 and 1.52 hours for each $0.01 \mathrm{~g} \mathrm{~mL}^{-1}$ of extract for wheat and radish, respectively) (Figure $3 \mathrm{~B}$ ).
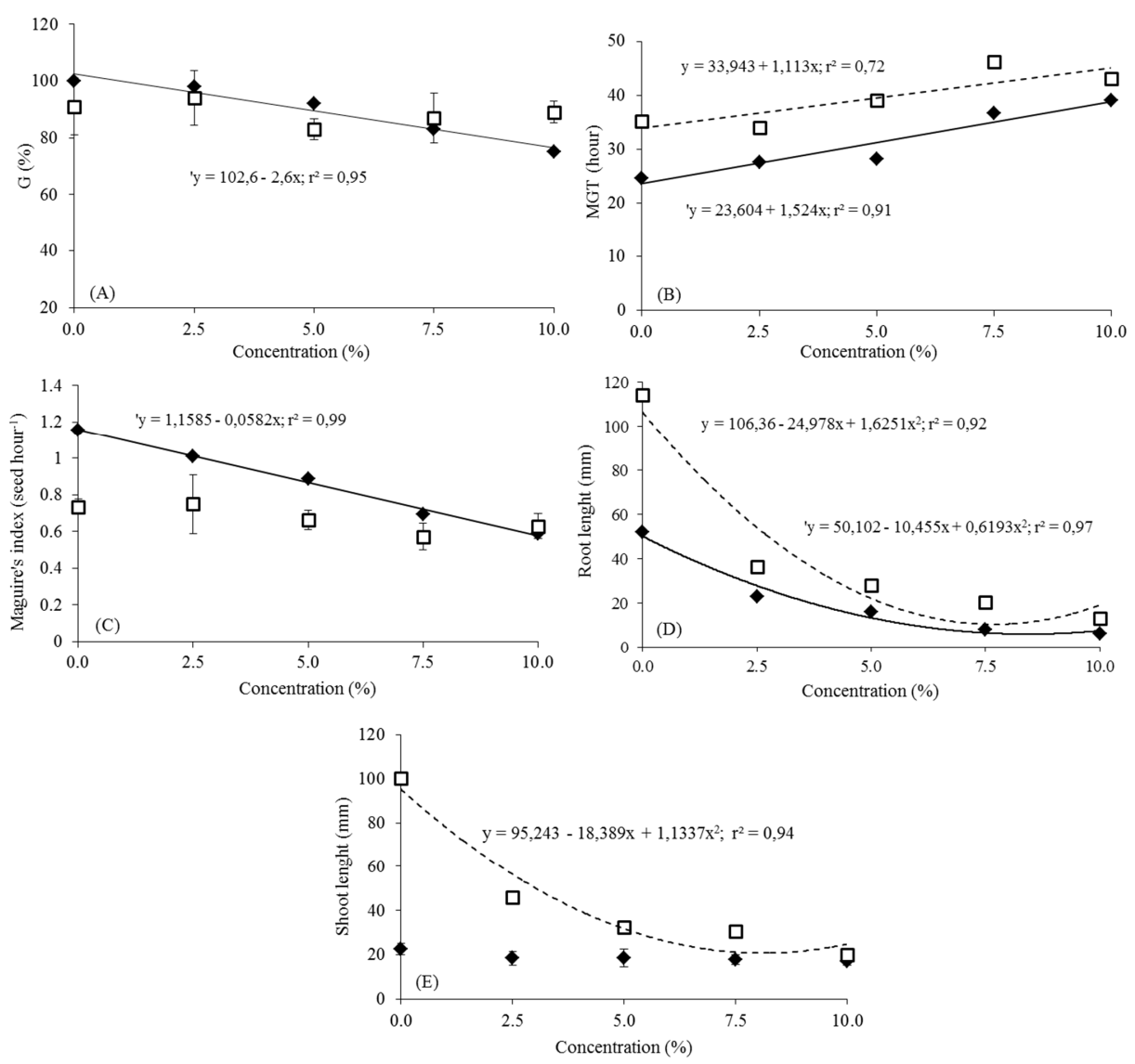

$\checkmark$ radish ('y)

$\square$ wheat (y)

Figure 3. (A) Germination (G\%), (B) mean germination time (MGT), (C) Maguire's Index in wheat $(T$. aestivum) and radish (R. sativus), early growth in (D) roots and (E) shoots when treated with $D$. brasiliensis Miers root extract at various concentrations. 
The germination speed of radish decreased linearly by 0.058 seed hour ${ }^{-1}$ for each $0.01 \mathrm{~g} \mathrm{~mL}^{-1}$ increase in extract concentration; however, the germination speed for wheat caryopses was not affected by the extract (Figure 3C). The early root growth of both species was strongly inhibited by the root extract. The wheat root length was minimal $(10.09 \mathrm{~mm})$ when using an estimated concentration
ANESE, S. et al.

of $7.68 \%$, and the root length of radish $(5.6 \mathrm{~mm})$ was minimal at an estimated concentration of $8.49 \%$ (Figure 3D). Regarding shoot growth, only wheat was affected by the root extract; the minimum value of this parameter $(20.42 \mathrm{~mm})$ was observed when using an estimated concentration of $8.10 \%$ (Figure 3E).
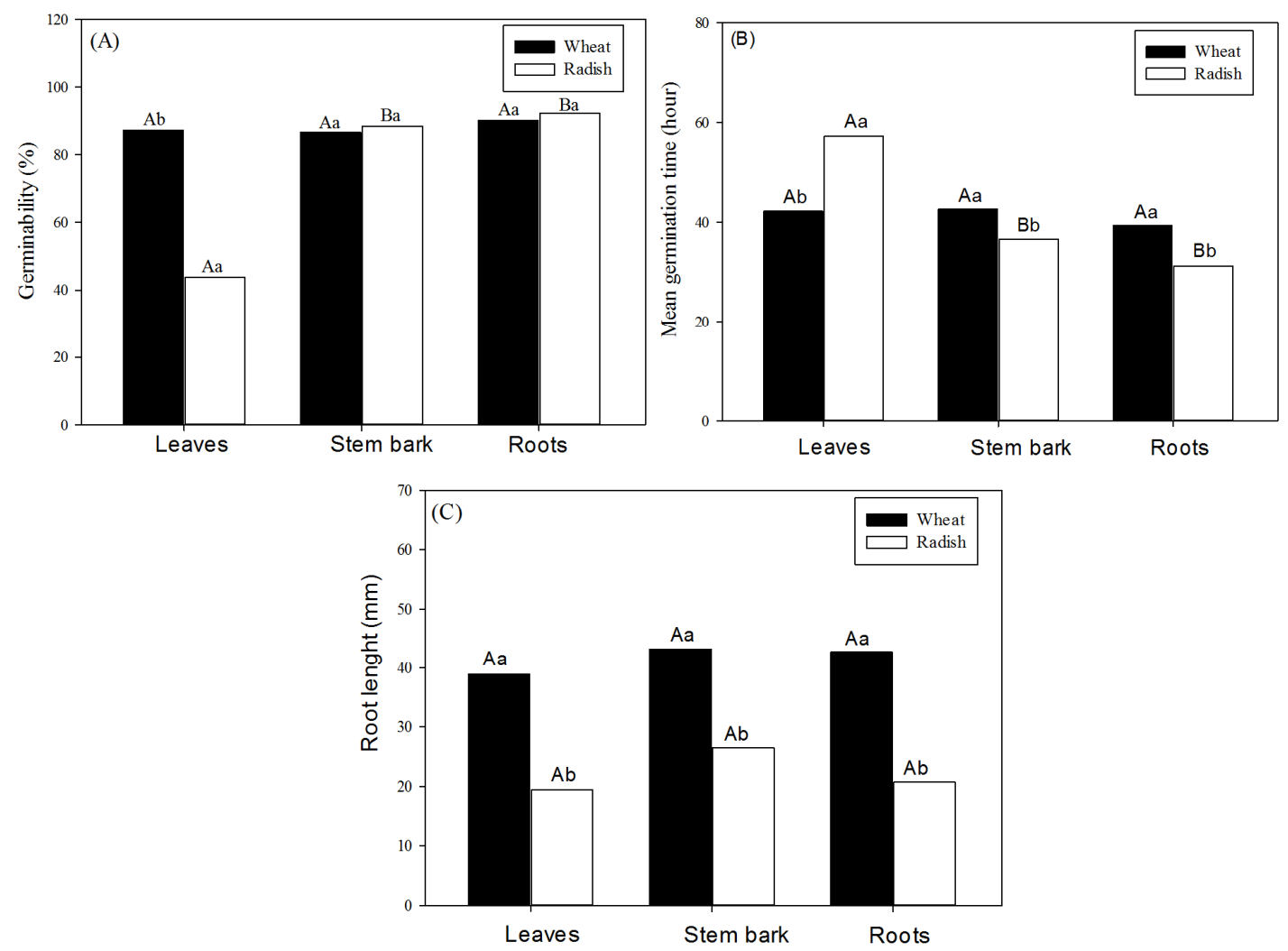

Figure 4. (A) Germination, (B) mean germination time (C) and root growth of T. aestivum and R. sativus subjected to treatment with different plant parts extracts of $D$. brasiliensis Miers. Means followed by the same lowercase letters for species and uppercase letters for plant parts do not differ according to the Tukey test at 0.05 probability.

Plant roots exude a complex variety of low molecular weight compounds to the environment. Some of the most complex physical, chemical and biological interactions experienced by land plants occur between their roots and the immediate soil environment (i.e., the rhizosphere) (BAIS et al., 2006). The biological role of exudates may be the key to understanding population dynamics and the role of allelopathy in this process (OLIVEROSBASTIDAS et al., 2009).

Root extracts might possess many inhibitory substances because roots are the main entry point of nutrients and water; because roots grow in the soil, they are more susceptible to attack by microorganisms and allelochemicals from neighboring plants (REZENDE et al., 2011). Due to the specificity of producing metabolites that are exudated directly in the environment, many compounds with relevant biological activities have been located almost exclusively in roots (OLIVEROS-BASTIDAS et al., 2009). Extracts and allelopathic phytotoxins obtained from roots have been reported to interfere in several plant development processes, including germination (SANTOS et al., 2007), root and shoot growth, normal seedling rate (LIU et al., 2011; GRISI et al., 2013), metaxylem cell growth (GATTI et al., 2010), photosynthesis, respiration and membrane transport (DAYAN et al., 2009). No records of the biological activity of $D$. brasiliensis roots are available in the 
literature, suggesting a need for further investigation of the phytotoxic properties of roots.

The results obtained for extracts of the different $D$. brasiliensis plant parts were compared using a joint analysis. Extracts of all plant parts exerted similar inhibitory effects on the germination and mean germination time of wheat, and no significant differences were observed between the extracts. However, the aqueous leaf extract of $D$. brasiliensis increased the mean germination time and reduced the germination rates of radish seeds, demonstrating that this extract inhibited the germination process of this species more effectively than the other plant parts evaluated (Figure 4A and 4B). Extracts of all plant parts were equally effective in inhibiting root growth in the two species tested (Figure 4C).

Secondary metabolites with phytotoxic activity are produced and located in several plant organs, including leaves, stems, bark, roots and fruits. However, the amounts differ among plant organs (PARVEZ et al., 2004; WESTON; DUKE, 2003). In this study, extracts of the leaves, stem bark and roots of $D$. brasiliensis exhibited phytotoxic effects on the two species tested. Several studies have shown that extracts obtained from various plant parts with allelopathic potential are able to suppress the germination or growth of treated plants. Sodaeizadeh et al. (2009) observed that all parts of Pegamum harmala showed phytotoxic effects on the germination and growth of weeds. Similarly, extracts of the leaves, bark and pods of Caesalpinia ferrea exert allelopathic activity on the development of lettuce seedlings (OLIVEIRA et al., 2012). However, aqueous extracts Mikania micrantha leaves exhibited greater phytotoxic effects than root extracts on the germination and shoot growth of woody species, whereas the aqueous root extracts affected the root growth of these species to a greater extent (WU et al., 2009).

In the present study, aqueous leaf extracts of D. brasiliensis inhibited radish germination more effectively than extracts of other plant parts; however, the same effect was not observed on wheat germination (Figure 4A and 4B). The differential sensitivity of these species to the effects of inhibitory substances depend on the mechanisms of physiological and biochemical resistance to these compounds that are specific for each target species and that result from evolutionary differences (HUNTER; MANGERS, 2002; KOBAYASHI, 2004). Allelopathic compounds that exhibit negative effects on the development of target plants at certain concentrations can cause less or no inhibition of the development of another species (XUAN et al.,
2005). In the present study, the greater allelopathic activity of $D$. brasiliensis leaves on radish may be due to differences in the concentration of allelochemicals or to differences in the chemical composition of the leaves and other plant parts of $D$. brasiliensis. However, the isolation and characterization of the allelopathic compounds present in the leaves, stem and roots of $D$. brasiliensis is needed to clarify the observed results.

The aqueous leaf, bark and root extracts had $\mathrm{pH}$ values of $4.18,4.33$ and 4.78 , respectively. Whereas germination and seedling growth are adversely affected by acidity or alkalinity extremes (GATTI et al., 2004), the $\mathrm{pH}$ of the D. brasiliensis plant part extracts most likely did not affect the characteristics evaluated. The osmotic potential values of the aqueous leaf, bark and root extracts were $-0.25,-0.14$ and $-0.08 \mathrm{MPa}$, respectively. The radish germination rates in PEG-6000 solutions with these osmotic potentials were 90,86 and $88 \%$, respectively and the wheat germination rates were 90, 92 and $90 \%$, respectively. These data did not differ from those obtained for the control group evaluated for each target species tested. Because the osmotic potentials of the extracts did not interfere with the germination of these species, the observed inhibitory effects on germination are attributable to the presence of allelopathic phytotoxins in the different plant extracts of $D$. brasiliensis. Drimane sesquiterpenes, aromatic dendrane-type sesquiterpenes, monoterpenes and flavonoids have been reported as secondary metabolites in the leaves and stem bark of $D$. brasiliensis (MECCHI; LAGO et al., 2013; SILVEIRA et al., 2012; LAGO et al., 2010; MALHEIROS et al., 2005) and might be involved in the phytotoxic activity observed. Further studies are needed to carry out to isolate and identify the secondary metabolites present in the different plant parts of D. brasiliensis and to confirm their phytotoxic properties. Such information could be used to develop environmentally friendly products for use as a strategic alternative, especially for weed control.

\section{CONCLUSIONS}

Extracts of the studied plant parts of $D$. brasiliensis exerted inhibitory effects on the germination and early growth processes of wheat and radish, and leaf extracts inhibited the germination of radish more effectively than the other extracts.

All of the studied $D$. brasiliensis plant parts constitute a promising source in search of phytotoxic compounds. 


\section{ACKNOWLEDGEMENTS}

The authors would like to thank Mr. Carlos Casali for assistance in collecting plant materials and CAPES and CNPq for financial support.

RESUMO: O objetivo deste trabalho foi avaliar o potencial fitotóxico dos extratos aquosos de folhas maduras, cascas do caule e raízes de Drimys brasiliensis Miers sobre a germinação e desenvolvimento inicial de plântulas de duas espécies receptoras, Triticum aestivumL. (trigo) e Raphanus sativus L. (rabanete). A partir do pó de cada material vegetal foram preparados extratos-tratamentos na proporção de $10 \mathrm{~g}$ de material vegetal para $100 \mathrm{~mL}$ de água destilada, produzindo-se a concentração de $10 \%$. A partir desta, foram feitas diluições em água destilada para 7,5; 5,0; 2,5\%, e $0 \%$ (controle). Bioensaios de germinação de diásporos e crescimento de plântulas foram desenvolvidos em condições controladas de laboratório. Os diferentes órgãos de $D$. brasiliensis exerceram efeitos inibitórios sobre os processos de germinação e crescimento inicial de trigo e rabanete, porém o extrato obtido a partir das folhas foi mais eficiente na inibição do processo de germinação do rabanete. Todos os órgãos de D. brasiliensis podem constituir uma fonte promissora na busca de compostos capazes de atuar como fitotoxinas naturais.

PALAVRAS-CHAVE: Inibição. Casca-de-anta. Trigo. Rabanete. Germinação. Crescimento inicial.

\section{REFERENCES}

ANDRADE, E. M.; BITTENCOURT, A. H. C.; VESTENA, S. Potencial alelopático de Cyperus rotundus L. sobre espécies cultivadas. Ciência e Agrotecnologia, Lavras, v. 33, Edição Especial, p. 1984-1990, 2009.

BAIS, H. P.; WEIR, T. L.; PERRY, L.G.; GILROY, S.; VIVANCO, J.G. The role of root exudates in rhizosphere interactions with plants and other organisms. Annual Review of Plant Biology, Palo Alto, v. 57, p. 233-266, 2006. http://dx.doi.org/10.1146/annurev.arplant.57.032905.105159

BORELLA, J.; WANDSCHEER, A. C. D.; PASTORINI, L. H. Efeito alelopático de extratos de folhas de Solanum americanum sobre o vigor do rabanete. Revista Trópica - Ciências Agrárias e Biológicas, São Luís, v. 6, n. 1, p. 44-51, 2012.

CALLAWAY, R. M. The detection of neighbors by plants. Trends in Ecololgy and Evolution, London, v. 17, n. 3, p. 104-105, 2002. http://dx.doi.org/10.1016/S0169-5347(01)02438-7

CECHINEL-FILHO, V.; SCHLEMPER, V.; SANTOS, A. R. S.; PINHEIRO, T. R.; YUNES, R. A.; MENDES, J. L.; CALIXTO, J. B.; MONACHE, F. D. Isolation and identification of active compounds from Drimys winteri barks. Journal of Ethnopharmacology, Leiden, v. 62, n. 3, p. 223-227, 1998.

http://dx.doi.org/10.1016/S0378-8741(98)00069-5

CLAUDINO, V. D.; DA-SILVA, K. C.; CECHINEL-FILHO, V.; YUNES, R. A.; DELLE-MONACHE, F.; GIMÉNEZ, A.; SALAMANCA, E.; GUTIERREZ-YAPU, D.; MALHEIROS, A. Drimanes from Drimys brasiliensis with leishmanicidal and antimalarial activity. Memórias do Instituto Oswaldo Cruz, Rio de Janeiro, v. 108, n. 2, p. 140-4, 2013.

CORRÊA, D. S.; TEMPONE, A. G.; REIMÃO, J. Q.; TANIWAKI, N. N.; ROMOFF, P.; FÁVERO, O. F.; SARTORELLI, P.; MECCH, M. C.; LAGO, H. G. Anti-leishmanial and anti-trypanosomal potential of polygodial isolated from stem barks of Drimys brasiliensis Miers (Winteraceae). Parasitology Research, Berlin, v. 109, n. 1, p. 231-236, 2011. http://dx.doi.org/10.1007/s00436-010-2229-8

DAYAN, F. E.; HOWELL, J. L.; WEIDENHAMER, J. D. Dynamic root exudation of sorgoleone and its in planta mechanism of action. Journal of Experimental Botany, Lancaster, v. 60, n. 7, p. 2107-2117, 2009. http://dx.doi.org/10.1093/jxb/erp082 
EHRENDORFER, F.; GOTTSBERGER, I. S.; GOTTSBERGER, G. Variation on the population, racial, and species level in the primitive relic angiosperm genus Drimys (Winteraceae) in South America. Plant Systematics and Evolution, Vienna, v. 132, n. 1-2, p. 53-83, 1979. http://dx.doi.org/10.1007/BF00983084

FAROOQ, M.; ZAHID, K. J.; CHEEMA, A.; WAHID, A.; SIDDIQUE, K. H. M. The role of allelopathy in agricultural pest management. Pest Management Science, Malden. v. 67, n. 5, p. 493-506, 2011. http://dx.doi.org/10.1002/ps.2091

FERREIRA, A. G.; ÁQUILA, M. E. A. Alelopatia: uma área emergente da ecofisiologia. Revista Brasileira de Fisiologia Vegetal, Rio Claro, v. 12, Edição Especial, p. 175-204, 2000.

GATTI, A. B.; FERREIRA, A. G.; ARDUIN, M.; PEREZ, S. C. J. G. A. Allelopathic effects of aqueous extracts of Aristolochia esperanzae O. Kuntze on development of Sesamum indicum L. seedlings. Acta Botânica Brasílica, São Paulo, v. 24, n. 2, p. 454-461, 2010. http://dx.doi.org/10.1590/S010233062010000200016

GATTI, B. A.; PEREZ, S. C. J. G. A.; LIMA, M. I. S. Atividade alelopática de extratos aquosos de Aristolochia esperanzae O. Kuntze na germinação e no crescimento de Lactuca sativa L. e Raphanussativus $\mathrm{L}$. Acta Botânica Brasílica, São Paulo, v. 18, n. 3, p. 459-472, 2004. http://dx.doi.org/10.1590/S010233062004000300006

GRISI, P. U.; RANAL, M. A.; GUALTIERI, S. C. J.; SANTANA, D. G. Allelopathic potential of Sapindus saponaria L. leaves in the control of weeds. Acta Scientiarum Agronomy. Maringá, v. 34, n. 1, p. 1-9, 2012.

GRISI, P. U.; GUALTIERI, S. C. J.; RANAL, M. A.; SANTANA, D. G. Influência alelopática do extrato aquoso de raiz de Sapindus saponária L. sobre capim-arroz e corda-de-viola. Bioscience Journal, Uberlândia, v. 29, n. 3, p. 760-766, 2013.

GUSMAN, G. S.; YAMAGUSHI, M. Q.; VESTENA, S. Potencial alelopático de extratos aquosos de Bidens pilosa L., Cyperus rotundus L. e Euphorbia heterophylla L. Iheringia, Série Botânica, Porto Alegre, v. 66, n. 1, p. $87-98,2011$.

HUNTER, M. E.; MENGES, E. S. Allelopathic effects and root distribution of Ceratiola ericoides (Empetraceae) on seven rosemary scrub species. American Journal Botany, St. Louis, v. 89, n. 7, p. 11131118, 2002.

INDERJIT; DUKE, S. O. Ecophysiological aspects of allelopathy. Planta, Berlin, v. 217, n. 4, p. 529-539, 2003. http://dx.doi.org/10.1007/s00425-003-1054-z

LAGO, G. H. G.; CARVALHO, L. A. C.; da SILVA, F. S.; TOYAMA, D. O.; FÁVERO, O. A.; ROMOFF, P. Chemical composition and anti-inflammatory evaluation of essential oils from leaves and stem barks from Drimys brasiliensis Miers (Winteraceae). Journal of the Brazilian Chemical Society, São Paulo, v. 21, n. 9 , p. 1760-1765, 2010. http://dx.doi.org/10.1590/S0103-50532010000900024

LIU, Y.; ZHANG, C.; WEI, S.; CUI, H.; HUANG, H. Compounds from the subterranean part of Johnsongrass and their allelopathic potential. Weed Biology and Management, Okayama, v. 11, n. 3, p. 160-166, 2011.

LORENZI, H. Árvores brasileiras: manual de identificação e cultivo de plantas arbóreas do Brasil, v. 1. 4 ed. Nova Odessa: Instituto Plantarum, 2002. 368 p.

KROYMANN, J. Natural diversity and adaptation in plant secondary metabolism. Current Opinion in Plant Biology, London, v. 14, n. 3, p. 246-251, 2011. http://dx.doi.org/10.1016/j.pbi.2011.03.021

KOBAYASHI, K. Factors affecting phytotoxic activity of allelochemicals in soil. Weed Biology and Management, Okayama, v. 4, n. 1, p. 1-7, 2004. 
KOUL, O.; WALIA, S. Comparing impacts of plant extracts and pure allelochemicals and implications for pest control. CAB Reviews: Perspectives in Agriculture, Veterinary Science, Nutrition and Natural Resources, v. 4, n. 49, p. 1-30, 2009.

MACÍAS, F. A.; OLIVEROS-BATIDAS, A.; MARÍN, D.; CARRERA, C.; CHINCHILLA, N.; MOLINILLO, J. M. G. Plant biocommunicators: their phytotoxicity, degradation studies and potential use as herbicide models. Phytochemistry Review, Netherlands, v. 7, n. 1, p. 179-194, 2008. http://dx.doi.org/10.1007/s11101007-9062-4

MALHEIROS, A.; CECHINEL-FILHO, V.; SCHMITT, C.B.; YUNES, R.A.; ESCALANTE, A.; SVETAZ, L.; ZACCHINO, S.; MONACHE, F. D. Antifungal activity of drimane sesquiterpenes from Drimys brasiliensis using bioassay guided fractionation. Journal of Pharmaceutical Sciences, Hoboken, v. 8, n. 2, p. 335-339, 2005.

MALHEIROS, A.; CECHINEL, V.; SCHMITT, C.; SANTOS, A.; SCHEIDT, C.; CALIXTO, J.; MONACHE, F.; YUNES, R.A Sesquiterpene drimane with antinociceptive activity from Drimys winteri bark.

Phytochemistry, London, v. 57, n. 1, p. 103-107, 2001. http://dx.doi.org/10.1016/S0031-9422(00)00515-X

MECCHI, M. C.; LAGO, J. H. G. Chemical constituents derived from Drimys brasiliensis Miers

(Winteraceae). Natural Product Research, London, v. 27, n. 20, 2013.

MENDES, G.; SANTOS, A.; CAMPOS, M.; TRATSK, K.; YUNES, R.; CECHINEL, V.; CALIXTO, J. Antihyperalgesic properties of the extract and of the main sesquiterpene polygodial isolated from the barks of Drimys winteri (Winteraceae). Life Science, Amsterdam, v. 63, n. 5, p. 369-381, 1998.

http://dx.doi.org/10.1016/S0024-3205(98)00285-9

MELLO-SILVA, R. Winteraceae in Lista de Espécies da Flora do Brasil. Jardim botânico do Rio de janeiro, 2013. Disponível em: http://floradobrasil.jbrj.gov.br/jabot/floradobrasil/FB15325. Acesso em: 27 mar. 2014.

MICHEL, B. E.; KAUFMANN, M. R. The osmotic potential of polyethylene glycol 6000. Plant Physiology, Waterbury, v. 51, n. 5, p. 914-916, 1973. http://dx.doi.org/10.1104/pp.51.5.914

OLIVEIRA, A. K.; COELHO, M. F. B.; MAIA, S. S. S.; DIÓGENES, F. E. P. Atividade alelopática de extratos de diferentes orgãos de Caesalpinia férrea na germinação de alface. Ciência Rural, Santa Maria, v. 42, n. 8, p. 1397-1403, 2012. http://dx.doi.org/10.1590/S0103-84782012000800011

OLIVEROS-BASTIDAS, A. J.; MACÍAS, F. A.; FERNÁNDEZ, C. C.; MARÍN, D.; MOLINILLO, J. M. G. Exudados de la raiz y su relevância actual em las interaciones alelopaticas. Química Nova, São Paulo, v. 32, n. 1, p. 198-213, 2009. http://dx.doi.org/10.1590/S0100-40422009000100035

PERIOTTO, F.; PEREZ, S. C. J. G. A.; LIMA, M. I. S. Efeito alelopático de Andira humilis Mart. ex Benth na germinação e no crescimento de Lactuca sativa L. e Raphanussativus L. Acta Botânica Brasílica, São Paulo, v. 18, n. 3, p. 425-430, 2004. http://dx.doi.org/10.1590/S0102-33062004000300003

PARVEZ, S.; PARVEZ, M.; FUJII, Y.; GEMMA, H. Differential allelopathic expression of bark and seed of Tamarindus indica L. Plant Growth Regulation, Boston, v. 42, n. 3, 245-252, 2004. http://dx.doi.org/10.1023/B:GROW.0000026493.95805.a5

PIMENTEL-GOMES, F. P. Curso de estatística experimental. 13.ed. Piracicaba: Nobel, 1990. 477p.

RANAL, M. A.; SANTANA, D. G. How and why to measure the germination process? Revista Brasileira de Botânica, São Paulo, v. 29, n. 1, p. 1-11, 2006. 
REICHEL, T.; BARAZETTI, J. F.; STEFANELLO, S. F.; PAULERT, R.; ZONETTI, P. C. Allelopathy of leaf extracts of jatropha (Jatropha curcas L.) in the initial development of wheat (Triticum aestivum L.). Idesia, Arica, v. 31, n. 1, p. 45-52, 2013.

REZENDE, G. A. A.; TERRONES, M. G. H.; REZENDE, D. M. L. C. Estudo do potencial alelopático do extrato metanólico de raiz e caule de Caryocar brasiliense Camb. (pequi). Bioscience Journal, Uberlândia, v. 27, n. 3, p. 460-472, 2011.

SANTOS, S.; MORAES, M. L. L.; REZENDE, M. O. O. Allelopathic potential and systematic evaluation of secondary compounds in extracts from roots of Canavalia ensiformis by capillary electrophoresis. Eclética Química, São Paulo, v. 32, n. 4, p. 13-18, 2007.

SILVEIRA, A. C. O.; CLAUDINO, V. D.; YUNES, R. A.; CECHINEL-FILHO, V.; MALHEIROS, A.; CORDOVA, C. M. M.; BELLA CRUZ, A. Antibacterial activity and toxicity of Drimys brasiliensis. Latin American Journal of Pharmacy, Buenos Aires, v. 31, n. 7, p. 935-40, 2012.

SILVESTRE, D.M.; KOLB, R.M.; FREI, F.; SANTOS, C. Phytotoxicity of organic extracts of Turnera ulmifolia L.and Turnera diffusa Willd.ex Schult. in cucumber seeds. Acta BotanicaBrasilica, Feira de Santana, v. 27, n. 3, p. 476-482, 2013.

SODAEIZADEH, H.; RAFIEIOLHOSSAINI, M.; HAVLI'K, J.; VAN DAMME, P. Allelopathic activity of different plant parts of Peganum harmala L. and identification of their growth inhibitors substances. Plant Growth Regulation, Boston, v. 59, n. 3, p. 227-236, 2009. http://dx.doi.org/10.1007/s10725-009-9408-6

SOUZA-FILHO, A. P. S.; GURGEL, E. S. C.; QUEIROZ, M. S. M.; SANTOS, J. U. M. Atividade alelopática de extratos brutos de três espécies de Copaifera (Leguminosae - Caesalpinioideae). Planta Daninha, Viçosa, v. 28, n. 4, p. 743-751, 2010.

SOUZA-FILHO, A. P. S.; ALVES, S. M. Potencial alelopático de plantas de acapu (Vouacapoua americana): efeitos sobre plantas daninhas de pastagens. Planta Daninha, Viçosa, v. 18, n. 3, p. 435-441, 2000.

TANVEER, A.; JABBAR, M. K., KAHLIQ, A.; MATLOOB, A.; ABBAS, R. N.; JAVAID, M. M. Allelopathic effects of aqueous and organic fractions of Euphorbia dracunculoides Lam. on germination and seedling growth of chickpea and wheat. Chilean Journal of Agricultural Research, Chillán, v. 72, n. 4, p. 495-501, 2012.

TRINTA, E. F.; SANTOS, E. Winteráceae. Flora Ilustrada Catarinense, Itajaí, 1997.

ULLAH, R.; TANVEER, A.; KHALIQ, A.; HUSSAIN, S. Comparative allelopathic potential of Fumaria indica L. and Polygonum plebejum L. against field crops. Pakistan Journal Weed Science Research, Peshawar, v. 19, n. 4, p. 5-29, 2013.

VIRTUOSO, S.; MIGUEL, O. G. Estudo fitoquímico e biológico de cascas de Erythrina velutina Willd. Fabaceae (Leguminosae - Papilionoideae). Visão Acadêmica, Curitiba, v. 6, n. 1, p. 89-90, 2005.

WESTON, L. A.; DUKE, S. O. Weed and crop allelopathy. Critical Reviews in Plant Sciences, Boca Raton, v. 22, n. 3-4, p. 367-389, 2003. http://dx.doi.org/10.1080/713610861

WU, A.; YU, H.; GAO, S.; HUANG, C.; HE, W.; MIAO, S.; DONG, M. Differential belowground allelopathic effects of leaf and root of Mikania micrantha. Trees, Berlin, v. 23, n. 1, p. 11-17, 2009.

http://dx.doi.org/10.1007/s00468-008-0249-0

XUAN, T. D.; SHINKICHI, T.; KHANH, T. D.; CHUNG, I. M. Biological control of weeds and plant pathogens in paddy rice by exploiting plant allelopathy: an overview. Crop Protection, Surrey, v. 24, n. 3, p. 197-206, 2005. 